\title{
BIRDS IN A PARTLY CLEARFELLED DRY EUCALYPT FOREST ON DOLERITE IN SOUTHEASTERN TASMANIA
}

\author{
by K.J.M. Dickinson, L.E. Wall and R.I. Wilson
}

(with two tables and three text-figures)

DICKINSON, K.J.M., WALL, L.E. \& WILSON, R.I., 1986 (12:ix): Birds in a partly clearfelled dry eucalypt forest on dolerite in southeastern Tasmania. Pap. Proc. R. Soc. Tasm. 120: 39-49.

https://doi.org/10.26749/rstpp.120.39 ISSN 0080-4703. Department of Geography, University of Tasmania, now Botany Department, University of Otago, Box 56, Dunedin, New Zealand; 63 Elphinstone Road, Mt Stuart, Tasmania; and 53 Blowhole Road, Blackmans Bay. Tasmania.

An area of dry eucalypt forest on dolerite in southeastern Tasmania was clearfelled in 1981. A portion of this area was subsequently slash-burnt and aerially sown in 1982, whilst the rest of the area was left unburnt and unsown. A monthly bird census was conducted during 1983-1984 in surrounding uncut, mature forest and also on the clearfelled area. Species were recorded together with the habitat in which they occurred and the particular plant species being utilised. A total of 46 avian species were recorded during the monthly censuses, with most species and individuals being observed in the spring months. The numbers of species and individuals recorded on the burnt and unburnt clearfelled areas were low in comparison with those observed in the uncut forest. In general, those species able to utilise open-ground habitats tended to be the least affected by clearfelling followed by slash-burning. However, the unburnt clearfelled area provided foraging sites for certain species, in preference to the nearby slash-burnt area. Many individuals recorded in the clearfelled areas made use of trees left standing after logging. The use of fire in dry forest management practice and the importance of cull trees are discussed.

Key Words: Tasmania, birds, clearfelled eucalypt forest, fire, forest management

\section{INTRODUCTION}

The large-scale exploitation of the dry eucalypt forests on dolerite in southeastern Tasmania began in 1971, with the provision of a woodchip market in Japan and a processing mill at Triabunna (fig. 1). Current forest management practice involves the logging of all merchantable trees (known as clearfelling) over large areas (termed coupes) typically 200 to 400 ha in size. In most cases clearfelling is followed by broadcast burning of slash (residue left after logging operations) and the sowing of eucalypt seed from the air.

The lack of data regarding the effects of clearfelling on wildlife has been emphasized by Conner \& Adkisson (1975) for North America, and by Statham (1984) for Australia. Fauna vary in their ability to withstand the disturbance, the most severely affected being those vertebrates and invertebrates which are dependent on mature trees for feeding and breeding (Franzreb 1977, Mcllroy 1978, Recher et al. 1981).

In Australia, information pertaining to the impact of forest utilisation on the avifauna is more extensive than for other vertebrate or invertebrate groups (e.g. Cowley 1971, Pattemore \& Kikkawa 1975, Woinarski 1979, Loyn 1980, Pattemore 1980, Smith 1985), probably because birds are easier to study on a regular basis (Statham 1984).

Clearfelling dramatically truncates the vertical vegetation structure of the natural forest.
Consequently, wildlife which can exploit open ground for both feeding and breeding tends to be the least affected in the first few years following cutting (Conner \& Adkisson 1975, Loyn et al. 1980 , Pattemore 1980). As the forest regenerates, birds have been observed to follow a succession in which different species become abundant as the structural diversity of the vegetation increases (Green 1980, Franzreb 1977, Loyn et al. 1980, Pattemore 1980).

The effect on fauna of forest management which involves the use of fire has received some attention. The influence of prescribed burning (generally involving fires of low to medium intensity) under mature or regenerating stands has been considered by Cowley et al. (1969), Leonard (1970), Cowley (1971), Christensen \& Kimber (1975), and Mcllroy (1978). Fuel reduction burning affects bird species which feed and nest on the ground (Cowley 1971) but little is known of the impact on wildlife of fires which occur at particular times of the year (Mcllroy 1978). Study of the effects of the hot, intense fires associated with slash-burning has been largely neglected (Pattemore 1980).

This paper seeks to provide some data on the effects of clearfelling, with and without slashburning, on wildlife within dry forests. Due to a limited a mount of time being a vailable a survey of the bird population was chosen as a means of giving some indication of the sensitivity of wildlife to habitat change. 


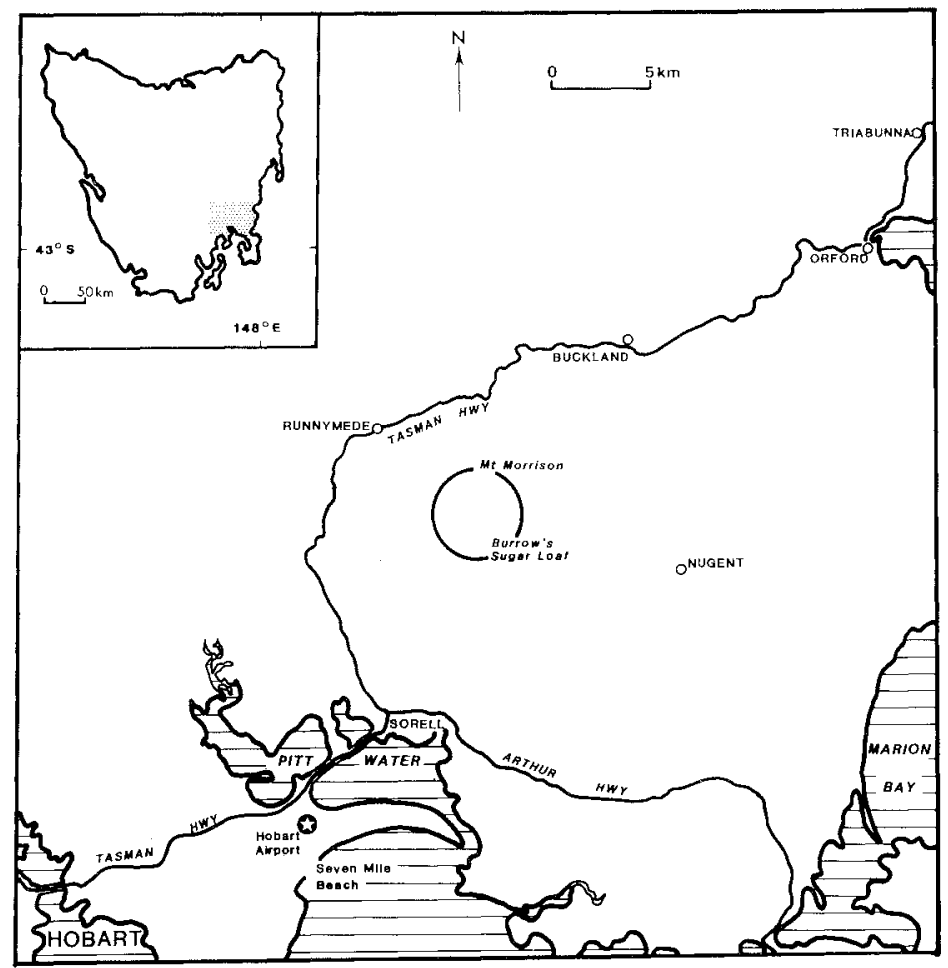

FIG.I - The location in southeastern Tasmania of the siudy area at MM14 (circled).

\section{METHODS}

A bird census was conducted in the environs of the coupe Mt Morrison block, compartment 14, hereafter referred to as MMl4 (fig. 1), which contained vegetation types typical of those found in dry eucalypt forests on dolerite in southeastern Tasmania. The study area chosen was within $6 \mathrm{~km}$ of the nearest pasture and formed part of an intensive investigation of vegetation and fuel dynamics following dry forest utilisation (Dickinson 1985).

The forest present within the coupe was treated in two ways:

(a) clearfelling followed by slash-burning and aerial sowing of eucalypt seed (hereafter referred to as treatment $\mathbf{B}$ ), and

(b) clearfelling without slash-burning or aerial sowing (hereafter referred to as treatment UB). Clearfelling took place in winter 1981, the slashburn on 11 January 1982 and the aerial sowing of seed in April 1982.

The census was carried out during 1983 and 1984 at approximately monthly intervals, with all surveys being undertaken during the morning between the hours of 0830 and 1200 . Individual surveys lasted approximately two hours. On each occasion the general weather conditions were noted (appendix 1). Bird species were recorded along a $3 \mathrm{~km}$ transect through uncut mature forest near to the coupe, with the route being chosen so as to cover the diversity of habitats present in the region of MM14 (fig. 2). The general habitats included:

1. Creekside vegetation which consisted of thick undergrowth close to a water course or soak. The plant species were represented by various graminoids, shrubs and small trees, such as Acacia melanoxylon, A. verticillata, Gahnia grandis, Lepidosperma laterale and Leptospermum lanigerum.

2. Forest dominated by Eucalyptus obliqua but with various other eucalypt species present, including $E$. globulus and E. viminalis. The understorey consisted of a combination of graminoids, ferns, small trees and shrubs, for example Acacia dealbata, Epacris impressa, Gahnia grandis, Leptospermum scoparium and Pteridium esculentum. 


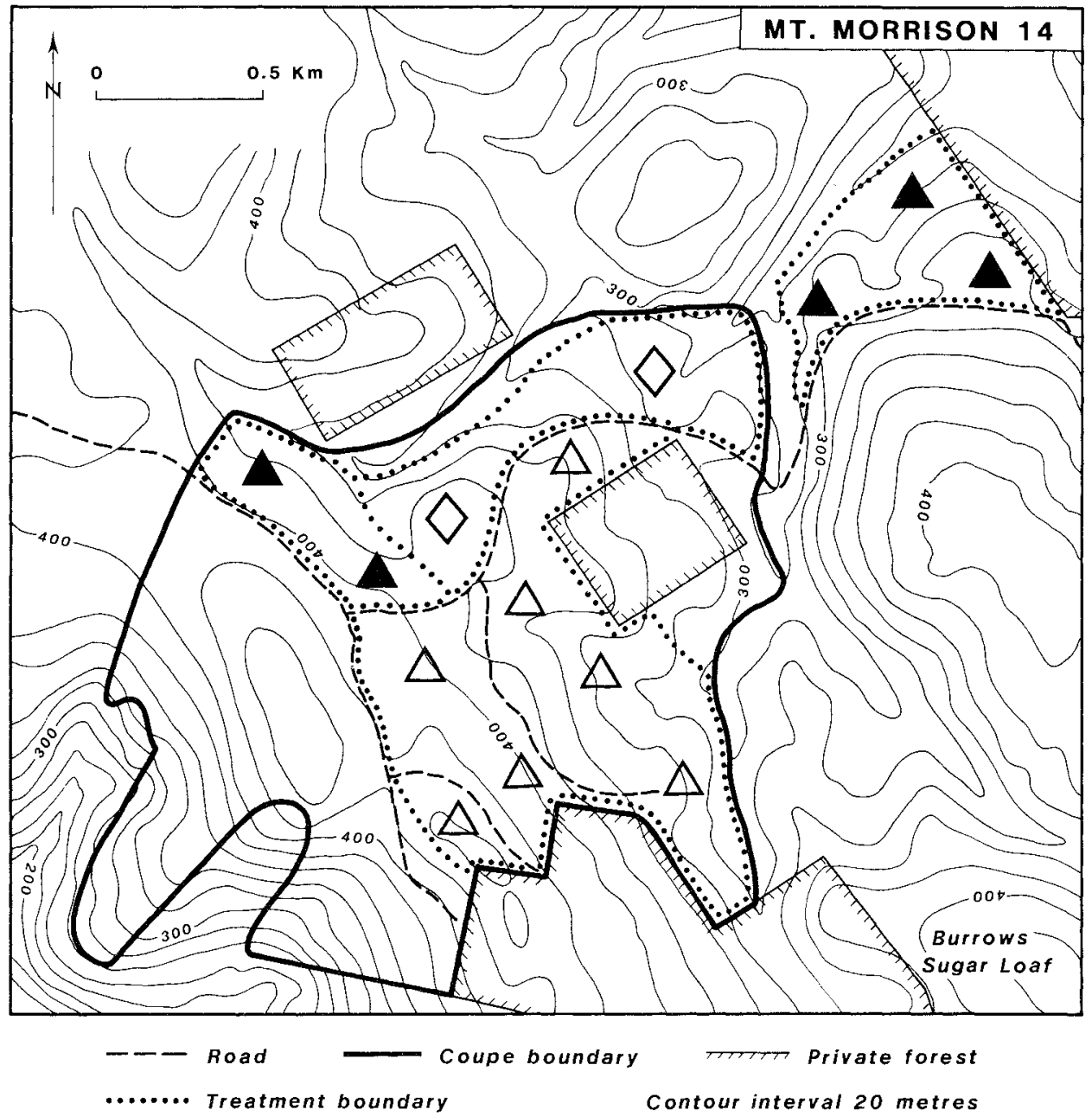

FIG.2 - The route of the monthly bird census at MMI4 through uncut forest ( $\boldsymbol{\Delta}$ ); on the area which had been clearfelled and slash-burnt,

3. Forest dominated by Eucalyptus pulchella interspersed with individuals of E. amygdalina $E$. globulus and $E$. viminalis. The understorey consisted generally of a sparse cover of herbs, graminoids, small shrubs and tussock grasses, for example Acacia dealbata, A. stricta Diplarrhena moraea, Helichrysum scorpioides, Lissanthe strigosa and Poa spp.

4. The margins of uncut forest, dominated by Eucalyptus obliqua, and the part of the coupe MM14 which had been slash-burnt (treatment B).

In addition, from March 1984 the census was
$B(\Delta) ;$ and on the area which was clearfelled but with the slash left unburnt, $U B(\diamond)$.

extended to include sweeps of the central areas of treatment B and treatment UB (fig. 2). On each occasion sweep duration was approximately 45 minutes and 30 minutes respectively.

In all censuses bird species were recorded either as actual sightings or as vocal records only, when the bird was not seen. In the case of sightings, the general habitat in which the bird species occurred was noted, as well as the activity in which the particular individual(s) was (were) engaged. Sightings were registered as single observations even when more than one individual of the species was present. Notes were also made of the plant 


\section{TABLE 1}

\section{The Total Number of Sightings and Total Number of Bird Species Recorded at MM14} During the Monthly Censuses in 1983 and 1984.

Part $\mathrm{A}=$ the total number of records and sightings, together with the frequency of sightings recorded in the various habitats in uncut forest. Air $=$ species recorded in flight at a height $>41 \mathrm{~m} ; \mathrm{Cr}=$ species recorded in creekside vegetation; $\mathrm{M}=$ species recorded crossing the margins of uncut forest and clearfelled coupe; $\mathrm{O}=$ species recorded in Eucalyptus obliqua dominated forest; $\mathrm{P}=$ species recorded in E. pulchella dominated forest. ( ) = species was very abundant in certain censuses with almost constant calling. Part $B=$ the total number of records and sightings recorded during the sweeps on treatments B and UB.

\begin{tabular}{|c|c|c|c|c|c|c|c|c|c|c|c|}
\hline \multirow[b]{3}{*}{ Species } & \multicolumn{7}{|c|}{ PART A } & \multicolumn{4}{|c|}{ PART B } \\
\hline & \multirow[t]{2}{*}{$\begin{array}{c}\text { Total } \\
\text { number of } \\
\text { sightings }\end{array}$} & \multirow[t]{2}{*}{$\begin{array}{c}\text { Total } \\
\text { number of } \\
\text { records }\end{array}$} & \multicolumn{5}{|c|}{$\begin{array}{l}\text { Frequency of sightings } \\
\text { General habitat }\end{array}$} & \multicolumn{2}{|c|}{$\begin{array}{c}\text { Total } \\
\text { number of } \\
\text { sightings }\end{array}$} & \multicolumn{2}{|c|}{$\begin{array}{c}\text { Total } \\
\text { number of } \\
\text { sightings }\end{array}$} \\
\hline & & & Air & $\mathrm{Cr}$ & $\mathbf{M}$ & $\mathbf{0}$ & $\mathbf{P}$ & B & UB & $\mathbf{B}$ & UB \\
\hline Wedge-tailed Eagle & 1 & 1 & 1 & - & - & - & - & - & - & - & - \\
\hline Brown Falcon & 4 & 4 & 4 & - & - & - & - & 1 & - & 1 & - \\
\hline Common Bronzewing & 1 & 2 & - & - & - & 1 & - & - & - & - & - \\
\hline Brush Bronzewing & 1 & 1 & $1-$ & - & - & 1 & - & - & - & - & - \\
\hline Green Rosella & 37 & 64 & 1 & 1 & 2 & 21 & 12 & 3 & 1 & 3 & 1 \\
\hline Blue-winged Parrot & - & - & - & - & - & - & - & 2 & - & 2 & - \\
\hline Pallid Cuckoo & 1 & 2 & - & - & - & - & 1 & - & - & - & _- \\
\hline Fan-tailed Cuckoo & 5 & 19 & - & - & - & 5 & - & - & - & - & - \\
\hline Laughing Kookaburra & 4 & 19 & - & - & - & 4 & - & - & 1 & 2 & 2 \\
\hline Skylark & - & - & - & - & - & - & - & 1 & - & 1 & - \\
\hline Welcome Swallow & 2 & 2 & - & - & 2 & - & - & 2 & - & 2 & - \\
\hline \multicolumn{12}{|l|}{ Black-faced } \\
\hline Cuckoo-shrike & 1 & 1 & - & - & - & 1 & - & - & - & $\ldots$ & - \\
\hline White's Thrush & 2 & 2 & - & - & - & 2 & - & - & - & - & - \\
\hline Flame Robin & 9 & 11 & - & - & - & 5 & 4 & 20 & 1 & 20 & 1 \\
\hline Scarlet Robin & 14 & 17 & - & 1 & 2 & 7 & 4 & 1 & 1 & 1 & 1 \\
\hline Dusky Robin & 17 & 20 & - & 1 & 6 & 10 & - & 10 & - & 13 & - \\
\hline Golden Whistler & 13 & 26 & - & - & 1 & 6 & 6 & - & 1 & 1 & 1 \\
\hline Grey Shrike-thrush & 30 & 68 & - & 1 & 4 & 21 & 4 & 5 & - & 7 & 1 \\
\hline Satin Flycatcher & 10 & (21) & - & 1 & - & 8 & 1 & - & - & - & - \\
\hline Grey Fantail & 54 & 58 & - & 17 & 2 & 30 & 5 & & - & & \\
\hline Spotted Quail-thrush & 4 & 4 & - & - & - & 1 & 3 & - & - & - & - \\
\hline Superb Fairy-wren & 71 & 76 & - & 20 & 19 & 20 & 12 & 31 & 6 & 31 & 8 \\
\hline \multicolumn{12}{|l|}{ White-browed } \\
\hline Scrub-wren & 17 & 21 & - & 13 & 1 & 3 & - & 1 & - & 1 & - \\
\hline Calamanthus & - & - & - & - & - & - & - & 1 & - & 1 & - \\
\hline Brown Thornbill & 82 & 91 & - & 13 & 10 & 41 & 18 & 4 & 7 & 4 & 7 \\
\hline Tasmanian Thornbill & 34 & 38 & - & 16 & - & 14 & 4 & 1 & - & 1 & - \\
\hline \multicolumn{12}{|l|}{ Yellow-rumped } \\
\hline Thornbill & - & 1 & - & - & - & - & - & 1 & - & 1 & - \\
\hline Yellow Wattlebird & 2 & 8 & - & - & 1 & - & 1 & - & - & - & - \\
\hline \multicolumn{12}{|l|}{ Yellow-throated } \\
\hline Honeyeater & 19 & 31 & - & - & - & 13 & 6 & - & 1 & - & 2 \\
\hline Strong-billed Honeyeater & 18 & 20 & - & - & - & 18 & - & - & - & - & - \\
\hline \multicolumn{12}{|l|}{ Black-headed } \\
\hline Honeyeater & 36 & 39 & - & - & 1 & 29 & 6 & - & - & - & 1 \\
\hline Crescent Honeyeater & 51 & 77 & 2 & 1 & - & 37 & 11 & - & 8 & - & 11 \\
\hline \multicolumn{12}{|l|}{ New Holland } \\
\hline Honeyeater & 1 & 1 & - & - & - & - & 1 & - & - & - & - \\
\hline Eastern Spinebill & 38 & 62 & - & 6 & 1 & 25 & 6 & 1 & 12 & 1 & 14 \\
\hline Spotted Pardalote & 11 & 20 & - & - & 1 & 9 & 1 & 1 & 1 & 1 & 1 \\
\hline
\end{tabular}




\begin{tabular}{|c|c|c|c|c|c|c|c|c|c|c|c|}
\hline \multirow[b]{3}{*}{ Species } & \multicolumn{7}{|c|}{ PART A } & \multicolumn{4}{|c|}{ PART B } \\
\hline & \multirow[t]{2}{*}{$\begin{array}{c}\text { Total } \\
\text { number of } \\
\text { sightings }\end{array}$} & \multirow[t]{2}{*}{$\begin{array}{l}\text { Total } \\
\text { number of } \\
\text { records }\end{array}$} & \multicolumn{5}{|c|}{$\begin{array}{l}\text { Frequency of sightings } \\
\text { General habitat }\end{array}$} & \multicolumn{2}{|c|}{$\begin{array}{c}\text { Total } \\
\text { number of } \\
\text { sightings }\end{array}$} & \multicolumn{2}{|c|}{$\begin{array}{c}\text { Total } \\
\text { number of } \\
\text { sightings }\end{array}$} \\
\hline & & & Air & $\mathrm{Cr}$ & $\mathbf{M}$ & $\mathbf{0}$ & $\mathbf{P}$ & B & UB & $\mathbf{B}$ & UB \\
\hline Striated Pardalote & 27 & $(52)$ & - & - & - & 20 & 7 & 4 & - & 4 & 3 \\
\hline Silvereye & 5 & 9 & - & l & - & 4 & - & 1 & - & 1 & - \\
\hline Beautiful Firetail & 6 & 6 & - & - & 5 & 1 & - & 2 & - & 2 & - \\
\hline Dusky Woodswallow & - & 1 & - & - & - & - & - & 1 & - & 1 & - \\
\hline Grey Butcherbird & 1 & 7 & - & - & - & - & 1 & - & - & - & - \\
\hline Black Currawong & 12 & 23 & 5 & 1 & 1 & 5 & - & - & 1 & 2 & 2 \\
\hline Grey Currawong & 7 & 16 & 1 & 1 & - & 4 & 1 & - & 2 & - & 2 \\
\hline Forest Raven & 10 & 21 & 8 & - & - & 1 & 1 & 1 & 1 & 2 & 1 \\
\hline
\end{tabular}

Additional species (recorded by call only): Yellow-tailed Black-Cockatoo, Shining Bronze-Cuckoo, European Goldfinch.

species associated with each sighting, together with the height class in which the bird species occurred. The latter were based on the structural divisions used in the TASFORHAB classification system (Peters 1985, see table 2). In addition, general observations of bird species occurring at MM14 were made during the years 1981 to 1984 . Nomenclature of bird species follows Schodde et al. (1977).

\section{RESULTS}

The English and scientific names of the bird species recorded at MM14 during 1981 to 1984 are given in appendix 2 . The 46 species recorded during the monthly censuses, as well as the total number of sightings and general habitat in which they were recorded, are presented in table 1.

\section{The Censuses Covering the Various Habitats in Uncut Forest}

The number of bird species, sightings and vocal records varied with season (fig. 3 ) and with weather conditions at the time of, and for the few days preceding the census (appendix 1). Feeding activity tended to be more pronounced if the census coincided with a period following inclement weather. Activity increased during the breeding season covered by the spring months of September and October, with the maximum number of species (27) being recorded in October 1983. The greatest number of sightings (77) was also made on the latter occasion. In comparison, the numbers of species, sightings and vocal records were low during the winter months of June to August (fig. 3).

Several species were absent or infrequent at certain times of the year, for example the Striated Pardalote was extremely abundant from September to November in both 1983 and 1984, whilst the Satin Flycatcher was abundant only from Novem- ber 1983 to February 1984, reappearing in the last census in November 1984. In contrast, the Crescent Honeyeater was most frequent during late autumn and winter.

The most frequently recorded species during the monthly censuses were the Brown Thornbill, Crescent Honeyeater, Superb Fairy-wren and Grey Shrike-thrush. Ten species, which included the Wedge-tailed Eagle, Spotted Quail-thrush and White's Thrush, were recorded on four or less occasions. However, Wedge-tailed Eagles were observed at other times, particularly on clear calm days, hunting in pairs over the coupe and surrounding forest. In February 1984, one pair was disturbed feeding on a freshly killed Bennett's wallaby (Macropus rufogriseus) within nearby mature forest dominated by Eucalyptus pulchella.

In general, the favoured habitats were those containing creekside vegetation and forest dominated by $E$. obliqua, although the situation was complicated by the varying lengths of transect through the different vegetation types. During the course of the censuses, 23 and 31 bird species were recorded in forest dominated by $E$. pulchella, and by $E$. obliqua respectively. The numbers of sightings and vocal records tended to be greater in $E$. obliqua dominated communities with certain species commonly occurring together, for example Blackheaded Honeyeaters and Strong-billed Honeyeaters often foraged in flocks through the foliage of $E$. obliqua. In the months of May to August it was not uncommon to have large sections of the transect where no sightings or vocal records were made. These gaps in observations would then be interspersed with pulses of bird species activity concentrated in particular areas of mature forest, generally those dominated by E. obliqua. This phenomenon was not so evident in the E. pulchella dominated habitats which were located on the more exposed, rocky ridges. In addition, on days 


\section{TABLE 2}

The Bird Species Recorded at MM14 During the Monthly Censuses in 1983 and 1984, Together with the Frequency of Their Occurrence in Eight Height Classes (m).

$\mathrm{A}=$ recorded in the various habitats in uncut forest (see text); $\mathrm{B}=$ recorded during the sweeps on treatment $B$; UB = recorded during the sweeps on treatment UB. Some individuals were recorded in more than one class.

\begin{tabular}{|c|c|c|c|c|c|c|c|c|c|c|c|c|c|c|c|c|c|c|c|c|c|c|c|c|}
\hline \multicolumn{25}{|c|}{ Height Class (m) } \\
\hline & \multicolumn{3}{|c|}{$0-2$} & \multicolumn{3}{|c|}{$2-5$} & \multicolumn{3}{|c|}{$5-8$} & \multicolumn{3}{|c|}{$8-15$} & \multicolumn{3}{|c|}{$15-27$} & \multicolumn{3}{|c|}{$27-41$} & \multicolumn{3}{|c|}{$>41$} & \multicolumn{3}{|c|}{ Flying $>41$} \\
\hline & $\mathbf{A}$ & $\mathbf{B}$ & UB & $\mathbf{A}$ & B & UB & $\mathbf{A}$ & B & UB & $\mathbf{A}$ & $\mathbf{B}$ & UB & $\mathbf{A}$ & B & UB & $\mathbf{A}$ & $\mathbf{B}$ & UB & $\mathbf{A}$ & B & UB & $\mathbf{A}$ & B & UB \\
\hline Wedge-tailed Eagle & - & - & - & - & - & - & - & - & - & - & - & - & - & - & - & - & - & - & - & - & - & 1 & - & - \\
\hline Falcon & - & - & - & - & - & - & - & - & - & - & - & - & - & - & - & - & - & - & - & - &.- & 4 & 1 & - \\
\hline 1on Bronzewing & - & - & - & - & - & - & - & - & - & - & - & - & - & - & - & - & - & - & - & سـ & - & - & - & - \\
\hline Brush Bronzewing & - & - & - & 1 & - & - & - & - & - & - & - & - & - & - & - & - & - & - & - & - & - & - & - & - \\
\hline Ros & 5 & 2 & 1 & 2 & - & - & 4 & - & 1 & 10 & 1 & - & 14 & - & - & 8 & - & - & - & - & - & 2 & - & - \\
\hline winged Parrot & - & 1 & - & - & - & - & س & 1 & - & - & - & - & - & 1 & - & - & 2 & - & - & - & - & - & - & - \\
\hline Cuckoo & $\ldots$ & - & - & - & - & - & - & - & - & - & - & - & 1 & - & - & - & $\ldots$ & - & - & $\ldots$ & - & - & - & 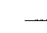 \\
\hline Fan- & 1 & - & - & - & - & - & - & - & - & 2 & - & - & - & - & - & 2 & - & - & - & - & - & - & - & - \\
\hline urra & - & - & - & - & - & - & - & - & - & 1 & - & - & 3 & - & - & - & - & 1 & - & - & - & - & - & - \\
\hline $\mathrm{Sk}$ & - & 1 & - & - & - & - & - & - & - & - & - & - & - & - & - & - & - & - & - & - & - & - & - & - \\
\hline Welcome Swallow & - & - & - & - & - & - & - & - & - & 2 & 2 & - & - & - & - & - & - & - & - & - & - & - & - & - \\
\hline \multicolumn{25}{|l|}{ Black-faced } \\
\hline Cuckoo-Shrike & - & $\ldots$ & - & - & - & - & - & - & - & $\ldots$ & - & - & - & - & - & - & - & - & 1 & -- & - & - & - & - \\
\hline - & 2 & - & - & - & - & - & - & - & 一. & - & - & - & - & - & - & - & - & - & - & 一 & - & - & - & - \\
\hline 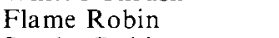 & 2 & 14 & 1 & 2 & 2 & - & 1 & 1 & - & 5 & 1 & - & 1 & 2 & - & - & - & - & - & - & - & - & - & - \\
\hline$n$ & 5 & 1 & - & 2 & - & - & 2 & - & 1 & 2 & - & - & 3 & $\ldots$ & - & 1 & - & - & - & - & - & - & - & - \\
\hline Du & 4 & 5 & - & 4 & 3 & -1 & 3 & - & - & 3 & 2 & - & 4 & - & - & - & - & - & - & - & - & - & - & - \\
\hline G & 2 & - & - & 2 & - & - & - & - & - & 1 & - & 1 & 6 & - & - & 3 & - & - & 1 & - & - & - & - & - \\
\hline $\mathrm{Gr}$ & - & - & - & 1 & 1 & - & 2 & 1 & - & 9 & 1 & 1 & 14 & 2 & - & 2 & - & - & 2 & - & - & - & - & - \\
\hline $\mathrm{Sa}$ & - & - & - & 2 & $\ldots$ & - & - & - & - & 2 & - & $\ldots$ & 5 & $\ldots$ & - & 2 & - & - & - & - & - & - & - & - \\
\hline $\mathrm{Gr}$ & 13 & - & - & 23 & - & -1 & 3 & - & - & 7 & - & - & 6 & - & - & 2 & - & - & - & - & - & - & - & - \\
\hline 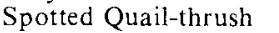 & 4 & - & - & - & - & - & - & - & - & - & - & - & - & - & - & - & - & - & - & $\ldots$ & - & -. & - & - \\
\hline Superb Fairy & 52 & 29 & 6 & 14 & 2 & 1 & 3 & - & - & 2 & - & - & - & - & - & - & - & - & - & - & - & - & - & - \\
\hline \multicolumn{25}{|l|}{ White-browed } \\
\hline Scrub-wren & 1 & 1 & - & - & - & - & - & - & - & - & - & - & - & - & - & - & - & - & - & - & - & - & - & - \\
\hline $\mathrm{Br}$ & & 2 & 1 & 20 & - & 1 & 3 & - & 1 & 15 & 2 & 3 & 16 & - & 2 & 8 & - & - & - & - & - & - & - & - \\
\hline $\mathrm{Ta}$ & & 1 & - & 10 & - & - & 4 & - & - & 6 & - & - & 1 & - & - & - & - & - & - & - & - & - & - & - \\
\hline & & & & & & & & & & & & & & & & & & & & & & & & \\
\hline $\mathrm{Tr}$ & - & - & - & - & - & - & - & 1 & - & - & - & - & - & - & - & - & - & - & - & - & - & - & - & - \\
\hline Yello & - & - & - & - & - & - & - & - & - & 1 & - & - & - & - & - & 1 & - & - & - & - & - & - & - & - \\
\hline & & & & & & & & & & & & & & & & & & & & & & & & \\
\hline $\mathrm{H}$ & - & - & - & 1 & - & - & 2 & - & 1 & 4 & - & - & 8 & - & - & 4 & - & - & 1 & - & - & $\ldots$ & - & - \\
\hline & & & & & & & & & & & & & & & & & & & & & & & & \\
\hline & - & - & - & - & - & - & 1 & - & - & 5 & - & - & 10 & - & - & 4 & - & - & I & - & - & - & - & - \\
\hline & & & & & & & & & & & & & & & & & & & & & & & & \\
\hline & - & - & - & 1 & - & - & - & - & - & 6 & - & - & 14 & -- & - & 15 & - & - & 1 & - & - & - & - & - \\
\hline Cre & 2 & - & - & 4 & - & 1 & 4 & - & 1 & 12 & - & 3 & 16 & - & 3 & 12 & - & - & 2 & - & - & - & - & - \\
\hline & & & & & & & & & & & & & & & & & & & & & & & & \\
\hline & - & - & - & - & - & - & - & - & - & - & - & - & - & - & - & - & - & - & 1 & - & - & - & - & - \\
\hline & 11 & 1 & 3 & 12 & - & 4 & 4 & - & 4 & 8 & - & 3 & 3 & - & - & - & - & - & - & - & - & - & - & - \\
\hline & - & $\div$ & - & - & - & - & - & - & - & 2 & - & 1 & 5 & 1 & - & 3 & - & - & 1 & - & - & - & - & - \\
\hline & - & 1 & - & 1 & - & - & - & - & - & 5 & 2 & - & 6 & 1 & - & 15 & - & - & - & - & - & - & - & - \\
\hline & 2 & - & - & 1 & $\ldots$ & - & 1 & - & - & - & - & $\cdots$ & - & 1 & - & 1 & - & - & - & - & - & - & - & $\ldots$ \\
\hline & - & 1 & - & 3 & 1 & - & - & - & - & 3 & - & - & - & $\ldots$ & - & 1 & - & - & - & - & - & - & - & - \\
\hline low & - & - & - & - & - & - & - & 1 & - & - & 1 & - & - & - & - & - & - & - & - & - & - & - & - & - \\
\hline & - & - & - & - & - & - & 1 & - & - & - & - & - & - & - & - & - & - & - & - & - & - & - & - & - \\
\hline & - & - & - & 1 & - & - & 1 & - & 1 & 2 & - & - & 2 & - & - & 1 & - & 1 & - & - & - & 6 & - & - \\
\hline & - & - & - & 1 & - & - & - & - & 1 & 2 & - & 1 & 1 & - & - & 2 & - & - & 1 & - & - & - & - & - \\
\hline Forest Raven & - & - & - & - & - & - & - & - & - & - & - & 1 & - & - & - & 1 & - & - & - & - & - & 9 & - & - \\
\hline
\end{tabular}

Additional species (recorded by call only): Yellow-tailed Black-Cockatoo, Shining Bronze-Cuckoo, European Goldfinch. 

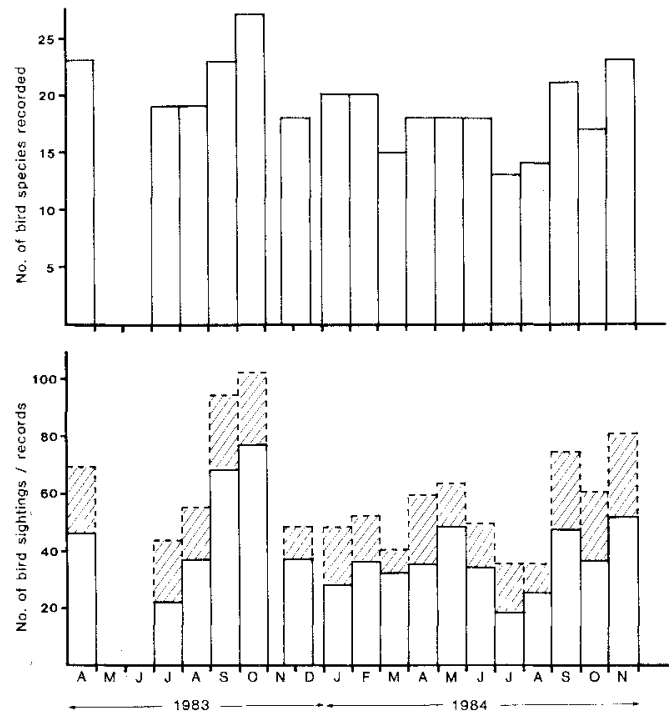

FIG.3 - The numbers of bird species recorded at MM14 during each of the monthly censuses in 1983 and 1984, together with the number of sightings and the number of vocal records (shaded) noted on each occasion. $N D=$ no data.

when there were strong winds bird activity tended to be concentrated in the more sheltered habitats, generally along creeks or on the lower slopes between ridges, rather than on the more exposed rocky sections.

The Tasmanian Thornbill, Brown Thornbill, Superb Fairy-wren, Grey Fantail and Whitebrowed Scrub-wren were the most commonly observed species in creekside vegetation. The Brown Thornbill and Superb Fairy-wren also frequented the areas where uncut forest abutted clearfelled coupe, as well as the Beautiful Firetail which was sighted crossing the forest margins on five out of a total of six occasions. However, it is likely that these species were more difficult to observe in the uncut forest.

The height classes in which bird species were recorded are given in table 2. The Spotted Quailthrush, White-browed Scrub-wren and White's Thrush were restricted to the lowest class of 0 to $2 \mathrm{~m}$. The Tasmanian Thornbill, Beautiful Firetail, Superb Fairy-wren and Flame Robin were most commonly sighted in classes up to $15 \mathrm{~m}$. The Grey Shrike-thrush, Black Currawong and Grey Currawong were more commonly observed above $8 \mathrm{~m}$. The Tasmanian endemics, the Yellow-throated Honeyeater, Black-headed Honeyeater and Strongbilled Honeyeater favoured the height classes from
8 to $41 \mathrm{~m}$. The Brown Thornbill, Crescent Honeyeater, Green Rosella and Grey Fantail were recorded feeding in the full range of height classes from 0 to $41 \mathrm{~m}$.

During the censuses several nests were observed belonging to the Forest Raven and Black Currawong, as well as two belonging to the Tasmanian endemic Yellow Wattlebird. Individuals of the Green Rosella were seen inspecting a hole in the trunk of an Eucalyptus viminalis tree in April 1983 after the end of the main breeding season, and juveniles were observed in January and February 1984. Spotted Pardalote juveniles were observed in November 1983 feeding in the foliage of E. obliqua, whilst evidence of nesting by the Striated Pardalote was recorded in September and October 1983, and November 1984. Juveniles of the Pallid Cuckoo (January 1984), Fan-tailed Cuckoo (February 1984), Superb Fairy-wren, Strong-billed Honeyeater (February 1984), Black-headed Honeyeater (February 1984), Satin Flycatcher (February 1984) and Grey Fantail (February 1984) were also observed. A Brown Thornbill was observed carrying nesting material in August 1984.

\section{The Censuses Covering the Sweeps on Treatments $\mathrm{B}$ and $\mathrm{UB}$}

The most commonly observed species on treatment B were the Superb Fairy-wren, Flame Robin and Dusky Robin (table 1). All were commonly seen feeding from 0 to $2 \mathrm{~m}$ or perched on dead trees or stumps (table 2). The Skylark, Blue-winged Parrot and Calamanthus were recorded only on treatment B (table 1). Small flocks of the Blue-winged Parrot, numbering up to 14 individuals, were observed consistently on treatment B either feeding on the ground or perched on dead trees from November to March in the years 1982/1983 and 1983/1984.

On treatment UB the most commonly observed species was the Eastern Spinebill which frequented the structural classes from 0 to $15 \mathrm{~m}$, feeding preferentially in the understorey vegetation from 0 to $5 \mathrm{~m}$. The Superb Fairy-wren did not favour treatment UB to the same extent as treatment $\mathrm{B}$, even allowing for the differences in length of the indiviual sweeps. The majority of the other species recorded on both treatments were seen perched or feeding in the foliage of the few standing trees (culls) which had retained their canopy following forest utilisation.

\section{DISCUSSION}

The seasonal and day-to-day variation in bird behaviour observed in this study has been 
noted elsewhere (e.g. Driscoll 1977, Ratkowsky \& Ratkowsky 1977, Pattemore 1980, Thomas 1980). Various species which were absent for much of the year from MMI4 are summer migrants which come to Tasmania from the Australian mainland, for example the Satin Flycatcher, Welcome Swallow and Blue-winged Parrot (Pattemore 1980). Most of the honeyeater species are nomadic with a tendency to move to low altitudes in winter (Thomas 1980). During the censuses at MM14 the Eastern Spinebill was particularly abundant when the heath species Epacris impressa was in flower, which generally occurred in late autumn and winter. In addition, the Crescent Honeyeater was noticeably more numerous in late autumn and winter. The increased activity of the Striated Pardalote at certain times of the year has also been observed within dry forests by Pattemore (1980), who noted a greater abundance of the species during the breeding season from November to February than in other months.

The influence of weather conditions on bird numbers which was observed during the present study has also been described by Ratkowsky \& Ratkowsky (1979) during surveys on Mt Wellington, near Hobart. Heavy rain or windy conditions may depress bird activity by reducing the availability of insects for forage (Franzreb 1977).

Dry sclerophyll forest in Tasmania supports 59 species out of a total of 70 regular forest birds (Thomas 1979). The total number of species in any one locality depends on the structural complexity, foliage density, and maturity of the forest (MacArthur \& MacArthur 1961, MacArthur 1964, Recher 1971, Loyn et al. 1980, Friend 1982). Moreover, bird populations tend to be greater in gullies than on ridges (see Loyn 1980, Smith 1984,1985). Where one habitat abuts on another, as in the case of the margins of uncut forest and the clearfelled coupe, a number of species can make use of both environments (c.f. Friend 1982).

Similar foraging habitats to those used by the avifauna observed at MMl4 have been described by Pattemore (1980) and Wilson (1981) both of whom wrote on the effect of forest utilisation on dry forest birds. Both authors describe mature forest as supporting the highest number of avian species whereas in contrast, areas which had been clearfelled supported low bird species numbers for the first few years following utilisation. The results from the sweeps on treatments B and UB at MM14 indicate that bird species which can exploit open ground habitats, such as the Superb Fairywren and Blue-winged Parrot, are able to utilise a slashburnt environment for at least two years after burning. However, unburnt slash can provide important foraging sites in their own right, as made evident by Conner \& Adkisson (1975) for some North American species, and by Loyn et al. (1980) for certain birds in Victoria

Nevertheless, not all species which utilise the lowest vegetation stratum of 0 to $2 \mathrm{~m}$ are unaffected by clearfelling. For example, White's Thrush, a species common in wet forest habitats (Blakers $e t$ al. 1984) but not usually associated with dry communities, was only recorded in undergrowth within the forest dominated by E. obliqua. In addition, some concern has been expressed over the status of the Spotted Quail-thrush in areas of clearfelled forest. The Spotted Quail-thrush was not recorded outside uncut forest at MM 14, however Pattemore (1980) observed the species in regrowth forest on a sandstone site which had not been slash-burnt. Wilson (1981) suggested that the species may better withstand logging activity if the forest is allowed to regenerate without the use of fire.

The importance of cull trees within clearfelled areas as foraging sites and perches for certain bird species has also been documented by Loyn ei al. (1980), who noted that the Dusky Woodswallow and Flame Robin required cull trees for both perches and nest sites. Dead standing trees within forest habitats have a multipurpose role in the life cycle of many fauna (McClelland \& Frissell 1975) making it important to identify, and retain, cull trees in any forest management practice. The nesting requirements of many Aust ralian landbirds have been emphasised by Disney \& Stokes (1976), who stated that in dry sclerophyll forest holes of suitable size for nesting may take in excess of 100 years to develop. Thus, from a wild life viewpoint the retention of cull trees of varying ages following clearfelling is likely to provide a supply of suitable breeding sites within the regenerating forest, until such time that the regrowth eucalypts form their own holes (c.f. Smith 1985). It can be seen that within a forest ind ustry managed on rotation cycles of less than 80 years, there is little chance that trees will have developed holes of suitable size and number to support the full range of dry forest fauna. Bowman \& Jackson (1981) quote possible rotation cycles in Tasmanian dry eucalypt forests of 40 to 50 years from Forestry Commission documentation, with the additional proviso that these time periods are open to amendment. The harvest rotation cycles currently proposed are of 80 to 90 years duration (Tasmanian Woodchip Export Study Group 1985). Of the avian species, examples of those most likely to be affected by a lack of suitable size holes are the Yellow-tailed Black- 
cockatoo and Swift Parrot, the Tasmanian endemic Green Rosella, and the owl species, the Southern Boobook and the Masked Owl, all of which feed and nest in mature trees (Pattemore 1980, Wilson 1981). Further research is needed into the optimal density and spacing of cull trees in order to maximise the forage, nest and perch sites available to wildlife in clearfelled areas.

Prescribed burning undertaken beneath the regenerating forest during the course of a particular forestry rotation cycle may be disadvantageous to some species, especially those which depend on ground habitats (e.g. Spotted Quail-thrush). The management strategy involving fires of varying intensity, patchy distribution and differing fire-free interval has been advocated by Cowley (1971), Christensen \& Kimber (1975), Loyn (1980), and Fox \& McKay (1981). In addition, a mosaic of mature forest covering habitats spanning ridges and gullies and linking different drainage areas, as well as regenerating stands of varying ages, is seen as a minimum requirement for wildlife management within any dry forest used by ind ustry (Loyn et al. 1980, Pattemore 1980, Recher et al. 1981, Statham 1984).

\section{ACKNOWLEDGEMENTS}

The study was undertaken with financial support from the Forest Ecology Research Fund, Tasmania.

\section{REFERENCES}

BLAKERS, M., DAVIES, S.J.J.F. \& REILLY, P.N., 1984: THE ATLAS OF AUSTRALIAN BIRDS. Melbuurne University Press, Melbourne

BOWMAN, D.M.J.S. \& J ACKSON, W.D., 1981: Slashburning in the regeneration of dry eucalypt forests. Aust. For. 44: 118-124.

CHRISTENSEN, P.E. \& KIMBER, P.C., 1975: Effect of prescribed burning on the flora and fauna of south-west Australian forests. Proc. Ecol. Soc. Aust. 9: 85-106

CONNER, R.N. \& ADKISSON, C.S., 1975: Effects of clearcutting on the diversity of breeding birds. $J$. For. 73: 781-785.

COWLEY, R.D., 1971: Birds and forest management. Aust. For. 35: 234-250

COWLEY, R.D., HEISLERS, A. \& EALEY, E.H.M. 1969:Effects of fire on wildlife. Victoria's Resources 11: 18-22.

DICKINSON, K.J.M 1985. VEGETATION AND FUEL DYNAMICS FOLLOWING CLEARFELLING OF DRY EUCALYPT FORESTS ON DOLERITE IN SOUTHEASTERN TAS-
MANLA WITH SPECIAL REFERENCE TO THE USE OF FIRE IN FOREST REGENERATION. Unpubl. Ph.D. thesis, University of Tasmania.

DISNEY, H.J. de S. \& STOKES, A., 1976: Birds in pine and native forests. Emu 76: 133-138.

DRISCOLL, P.V., 1977: Comparison of bird counts from pine forests and indigenous vegetation. Aust. Wildl. Res. 4: 281-288.

FOX, B.J. \& McKAY, G.M., 1981: Small mammal responses to pyric successional changes in eucalypt forest. Aust. J. Ecol. 6: 29-41.

FRANZREB, K.E., 1977: Bird population changes after timber harvesting of a mixed conifer forest in Arizona. U.S. Dept Agric. For. Serv. Res. Pap. RM-184

FRIEND, G.R., 1982: Bird populations in exotic pine plantations and indigenous eucalypt forests in Gippsland, Victoria. Emu 82: 80-89.

GREEN, R.H., 1980: Birds in initial eucalypt regeneration. Paper presented to $78 \mathrm{th}$ Annual Congress RAOU, Hobart, Dec. 1980

LEONARD, B., 1970: Effects of control burning on the ecology of small mammal populations. Pap. 2nd Fire Ecol. Symp., Monash Univ., Nov. 1970. For. Comm. Vict.

LOYN, R.H., 1980: Bird populations in a mixed eucalypt forest used for the production of wood in Gippsland. Emu 80: 145-156.

LOYN, R.H., MACFARLANE, M.H., CHESTERFIELD, E.A. \& HARRIS, J.A., 1980: Forest utilisation and the flora and fauna in Boola Boola State Forest in south-eastern Victoria. For. Comm. Vict. Bull. No.28.

MacARTHUR, R.H., 1964: Environmental factors affecting bird species diversity. Am. Nat. 98: 387-397.

MacARTHUR, R.H, \& MacARTHUR, J.W., I961: On bird species diversity. Ecol. 42: 594-598.

McCLELLAND, B.R. \& FRISSELL, S.S. 1975: Identifying forest snags useful for hole-nesting birds. $J$. For. 73: 414-417

McILROY, J.C., 1978: The effects of forestry practices on wildlife in Australia: a review. Aust. For. 41 : 78-94.

PATTEMORE, V., 1980: Effects of the pulpwood industry on wildlife in Tasmania. 3. Succession in bird communities and their habitats. NPWS Tasm. Wildl. Div. Tech. Repi 80/1.

PATTEMORE, V. \& K1KKAWA, J., 1975: Comparison of bird populations in logged and unlogged rainforest at Wiangarie State Forest, N.S.W. Aust. For. 37: 188-198.

PETERS, D.G., 1985: TASFORHAB. In MYERS, K., MARGULES, C.R. \& MUSTO, I, (Eds): SURVEY METHODS FOR NATURE CONSERVATION. Vol.2: 47-66. CSIRO Div. Water \& Land Resources, Canberra.

RATKOWSKY, A.V. \& RATKOWSKY, D.A., 1977: The birds of the Mt Wellington Range, Tasmania. Emu 77: 19-22. 
RATKOWSKY, A.V. \& RATKOWSKY, D.A., 1979: A comparison of counting methods to obtain bird species numbers. Notornis 26: 53-61.

RECHER, H.F., 1971: Bird species diversity: a review of the relation between species number and environment. Proc. Ecol. Soc. Aust. 6: 135-152.

RECHER, H.F., LUNNEY, D., SMITH, P. \& ROHANJONES, W., 1981: Woodchips or wildlife? Aust. Nat. Hist. 20: 239-244.

SCHODDE, R., GLOVER, B., KINSKY, F.C., MARCHANT,S., McGILL, A.R. \& PARKER, S.A., 1977: Recommended English names for Australian birds. Emu 77: 245-307.

SMITH, P., 1984: The forest avifauna near Bega, New South Wales. I. Differences between forest types. Emu 84: 200-210.

SMITH, P., 1985: Effects of intensive logging on birds in eucalypt forest near Bega, New South Wales. Emu 85: 15-21.
STATHAM, H.L., 1984: The effects of forest operations on wildlife in Tasmania. Report for the Forest Ecology Research Fund, Tasmania.

TASMANIAN WOODCHIP EXPORT STUDY GROUP, 1985: Environmental Impact Statement on Tasmanian Woodchip Exports Beyond 1988. Draft Rept. Govt Printer, Hobart.

THOMAS, D.G., 1979: TASMANIAN BIRD ATLAS Fauna of Tasmania Handbook No.2. University of Tasmania, Hobart.

THOMAS, D.G., 1980: Foraging of honeyeaters in an area of Tasmanian sclerophyll forest. Emu 80: $55-58$.

WILSON, R.I., 1981: The woodchip industry and Tasmanian birds. Tas. Bird Rept, No.11:11-14.

WOINARSKI, J.C.Z., 1979: Birds of a Eucalyptus plantation and adjacent natural forest. Aust. For. 42: 243-247.

(accepted Sept. I, 1985)

\section{APPENDIX 1}

The Dates of the Bird Censuses Undertaken at MM14 During 1983 and 1984, Together with Descriptions of the Prevailing Weather Conditions.
Date of Census

\section{Weather Conditions}
12.4 .83
5.7 .83
3.8 .83
10.9 .83
Clear skies. Very light breeze. Warm.
Clear skies. Calm. Cool-warm. (Previous 10 days severe frosts and snow.)
Clear skies. Very light breeze. Cold.
Intermittent light cloud. Light $\mathrm{N}$ breeze.
5.10 .83
Cool-warm. (Previous 5 days almost constant rain.)
30.11 .83
95\% cloud cover. Light S breeze. Cool.
3.1 .84
$100 \%$ cloud cover. Strong N breeze. Cool-warm.
7.2 .84
$30 \%$ to $100 \%$ cloud cover. Strong SW breeze. Cool
1.3 .84
3.4 .84
$10 \%$ cloud cover, Moderate N breeze. Cool-warm.
95\% cloud cover. Very light breeze. Cold-cool following heavy rain.
2.5 .84
19.6 .84
12.7 .84
$5 \%$ cloud cover. Light W breeze. Warm.
Clear skies. Calm. Cold-cool.
$100 \%$ cloud cover. Calm. Cold.
9.8 .84
$30 \%$ to $100 \%$ cloud cover. Calm. Cold-cool.
13.9.84
$100 \%$ cloud cover. Moderate $\mathrm{N}$ breeze. Cool
8.10 .84
$100 \%$ cloud cover (light high altitude cloud). Light NE breeze. Cool-warm.
14.11 .84
$100 \%$ cloud cover. Strong N breeze. Cool-warm.
$15 \%$ cloud cover. Moderate SE breeze. Cool-warm following heavy rain. 
APPENDIX 2

Bird Species Observed at MM14 During the Years 1981-1984

Nomenclature follows Schodde et al. 1977). ${ }^{*}=$ species endemic to Tasmania.

Wedge-tailed Eagle

Brown Falcon

Common Bronzewing

Brush Bronzewing

Yellow-tailed Black-Cockatoo

Swift Parrot

* Green Rosella

Blue-winged Parrot

Pallid Cuckoo

Fan-tailed Cuckoo

Shining Bronze-Cuck oo

White-throated Needletail

Laughing Kookaburra

Skylark

Welcome Swallow

Tree Martin

Black-faced Cuckoo-shrike

White's Thrush

Flame Robin

Scarlet Robin

* Dusky Robin

Olive Whistler

Golden Whistler

Grey Shrike-thrush

Satin Flycatcher

Grey Fantail

Spotted Quail-thrush

Superb Fairy-wren

White-browed Scrub-wren

Calamanthus

Brown Thornbill

* Tasmanian Thornbill

Yellow-rumped Thornbill

* Yellow Wattlebird

* Yellow-throated Honeyeater

* Strong-billed Honeyeater

* Black-headed Honeyeater

Crescent Honeyeater

New Holland Honeyeater

Eastern Spinebill

Spotted Pardalote

Striated Pardalote

Silvereye

European Goldfinch

Beautiful Firetail

Dusky Woodswallow

Grey Butcherbird

* Black Currawong

Grey Currawong

Forest Raven
Aquila audax

Falco berigora

Phaps chalcoptera

Phaps elegans

Calyptorhynchus funereus

Lathamus discolor

Platycercus caledonicus

Neophema chrysostoma

Cuculus pallidus

Cuculus pyrrhophanus

Chrysococcyx lucidus

Hirundapus caudacutus

Dacelo novaeguineae

Alauda arvensis

Hirundo neoxena

Cecropis nigricans

Coracina novaehollandiae

Zoothera dauma

Petroica phoenicea

Petroica multicolor

Melanodryas vittata

Pachycephala olivacea

Pachycephala pectoralis

Colluricincla harmonica

Myiagra cyanoleuca

Rhipidura fuliginosa

Cinclosoma punctatum

Malurus cyaneus

Sericornis frontalis

Sericornis fuliginosus

Acanthiza pusilla

Acanthiza ewingii

Acanthiza chrysorrhoa

Anthochaera paradoxa

Lichenostomus flavicollis

Melithreptus validirostris

Melithreptus affinis

Phylidonyris pyrrhoptera

Phylidonyris novaehollandiae

Acanthorhynchus tenuirostris

Pardalotus punctatus

Pardalotus striatus

Zosterops lateralis

Carduelis carduelis

Emblema bella

Artamus cyanopterus

Cracticus torquatus

Strepera fuliginosa

Strepera versicolor

Corvus tasmanicus 